\title{
Short-Term Return Impact of Share Repurchase Announcements
}

\author{
Ahmet Tasdemir ${ }^{1 *} \quad$ Erkan Alsu ${ }^{2}$ \\ 1.Gaziantep University, Faculty of Economics and Administrative Sciences, Department of Business \\ Administration \\ 2.Assist. Prof., Gaziantep University, Faculty of Economics and Administrative Sciences, Department of \\ Business Administration
}

\begin{abstract}
Share repurchase transactions are seen as a corporate financing tool that plays a substantial role in the distribution of idle cash within the company, and are often considered as an alternative to cash dividend payments. The purpose of this study is to determine the effect of the share repurchase programs announcements on stock returns in Turkey stock market. In this study focused on, the effect of the 146 announcements on the stock returns of the companies that are traded in Borsa Istanbul between the years 2010-2018 which initiated share repurchase programs was examined by the event study method. As the conclusion of the study, it was determined that share repurchase announcements produced statistically significant cumulative abnormal returns before and after the announcement date. Also, considering CAAR values calculated in the realization of the share repurchase announcements result in international markets, the impact on stock returns of the share repurchase announcements in Turkey, compared to many other countries, were found to be suggestively higher. Keywords: Share Repurchase, Stock Returns, Abnormal Return, Cumulative Abnormal Return, Event Study.

DOI: $10.7176 /$ RJFA/10-12-03
\end{abstract}

Publication date:June $30^{\text {th }} 2019$

\section{Introduction}

Nowadays, companies are expected to make a choice between retaining a portion of their earnings within the company in the name of maintaining a continuity in their operations or distributing those to their partners in order to appeal to the interest of investors. When companies prefer to distribute their earnings to their partners, two options appear before them; to give cash to shareholders directly in the form of dividends or to make share repurchases. By engaging in share repurchasing, companies accomplish reducing the total amount of shares offered, shall increase the impact of the remaining shares on future cash flow, and shall actualize the distribution of some type of non-cash dividends to investors in doing so. When the studies related to how companies evaluate these two options are examined however, two different situations emerge. It was observed that before 1980's, companies preferred mostly to pay dividends to their shareholders, whereas after 1980 's, this situation was reversed and they rather favored to engage in share repurchasing practices (Skinner, 2008). This situation was influenced by the adoption of rule 10b-18 by the US Securities and Exchange Commission (SEC) in 1982. This rule in particular, determines the principles of engaging in share repurchasing activities and abridging the barriers to initiating a program (Grullon and Michaely, 2002).

Share repurchasing is one of the most widely applied methods of profit distribution by many companies in the market today, which was started to be implemented in 1982 when US Securities and Exchange Commission (SEC) adopted Rule 10b-18. Companies actualize billions of dollars' worth of share repurchase programs each year. For example, while the companies in the United States repurchased shares worth approximately $\$ 158$ billion only in February 2018, experts expect this figure to reach $\$ 800$ billion by the end of the year (Fox, 2018).

Interest in this scheme has notably increased as share repurchasing provides many advantages in terms of shareholder value maximization, which is the main business objective of companies after all. Among the enterprises listed in the S\&P 500 index, which is one of the foremost indices of the United States, 362 companies acquired a total of $\$ 115.6$ billion only in the third quarter of 2016. It is observed that the share repurchasing activities which had considerably decreased during the period of 2008-2009 global economic crisis, have reached fairly significant sizes in recent years. Similar to the United States, companies in developed countries such as Japan, Canada, France and Germany, as well as companies in developing countries such as Malaysia, South Korea and Brazil, are recognized to announce rigorous share repurchasing programs (Manconi, Peyer and Vermaelen, 2015).

Although applied for many years in the world markets and becoming more and more popular at the present time, share repurchasing started to be implemented in Turkey merely after 2009. Following the decision taken at the end of 2009 which provided a limited number of companies with the share repurchasing opportunity, with the new Turkish Commercial Code coming into force on July 1, 2012, the obstacles before the companies in repurchasing their shares have been relaxed, and since then, the number of companies inclined towards share repurchasing increased every passing year.

However, despite the increasing interest of companies in share repurchasing practices, domestic literature 
has been found to be quite limited in this area. For this reason, it is aimed to examine the share repurchases of the companies traded on the Borsa Istanbul (BIST) and to provide a comprehensive study from which company executives, investors, and future researches alike would benefit from.

\section{Literature Review}

"Becoming more and more popular over time in the world markets, share repurchasing practices have intensified the interest of researchers in this field as well and have led to many studies conducted specifically in this area. The body of literature is inundated with studies investigating the objectives of companies in engaging share repurchasing activities. The most common objectives are reported to be distribution of excess cash, rearrangement of the capital structure, and application of more appropriate tax rates. In addition, there are also studies examining the abnormal returns on the dates of repurchase activities.

Introductory studies such as Vermaelen (1981, 1984), Netter and Mitchell (1989), Lakonishok and Vermaelen (1990), Comment and Jarell (1991), Ikenberry et al. (1995), Stephens and Weisbach (1998), Grullon and Michaely (2004) and Peyer and Vermaelen (2005), were all focalized on the US market. All these studies revealed significant positive returns around $3 \%$ on the dates when the share repurchase programs were announced in the US markets. On the other hand, in their studies conducted for the United Kingdom, Lasfer (2000) and Rau and Vermaelen (2002), illustrated that the returns were much smaller compared to the US and presented to be around 1\%. In the Hackethal and Zdantchouk (2006) study in which share repurchases in Germany were scrutinized, even though percentage of positive returns were found out to be higher than of the UK, the positive returns yielded by the share repurchase announcements in this market were found to be behind the United States. Hatakeda and Isagawa (2004), in their study for Japan, discussed share repurchase announcements in two groups; those which resulted into de facto repurchases, and those which did not and determined that the positive return rate of about $1 \%$ found throughout the market as a result of the repurchase announcements of these groups was similar to that of the United Kingdom.

Moreover, Liao, Ke and Yu (2005), Zhang (2005) and McNally, Smith and Barnes (2006) examined share repurchases in Taiwan, Hong Kong, and Canada, respectively. Liao et al., (2005) identified positive returns on the date of repurchase announcement, but determined that these positive returns were limited to a few days that immediately followed the announcement. Zhang (2005) determined a positive abnormal return on the repurchase dates and established that the firms that made the repurchases differed according to their size and PD/DD values. McNally et al. (2006) on the other hand, found evidences that repurchases provided price support and that companies which were engaged in repurchasing practices had better timings.

Nonetheless, in recent studies conducted, Andriosopoulos and Lasfer (2015) found that the market response to repurchase announcements in European countries was lower than of the repurchase announcements made in the US markets. In addition, Manconi, Peyer and Vermaelen (2015) in their study where they examined share repurchases in 32 countries, in both the short and long-term periods, they observed positive returns in repurchase announcements made in countries outside the United States, but found that these returns were lower in percentage than those yielded in the US markets. In their study conducted in India, Chatterjee and Dutta (2015) examined the impact of stock repurchase announcements made by companies traded in the Mumbai stock exchange on the stock prices, and from the results obtained, they concluded that the repurchase announcements made in the Mumbai stock market, in contrast to those in developed economies such as the United States, Canada and Australia, were not begirded by positive abnormal returns.

Isa and Lee (2015), on the other hand, measured in their work the market reaction for each of the three different announcements stating the decision of the board of directors, the approval of the shareholders, and the commencement dates of the repurchases, and concluded that the market has reacted positively to all these three announcements. Moreover, studies like Ikenberry, Lakonishok and Vermaelen (1995), Ikenberry, Lakonishok and Vermaelen (2000), Chan, Ikenberry and Lee (2004), Zhang (2005), Peyer and Vermaelen (2009) and Yook (2010), examined the long-term effects of repurchase announcements, and as a result of these studies, long-term abnormal returns up to 48 months were identified.

\section{Data And Methodology}

Within the scope of the research, repurchase announcements made by all publicly traded companies in BIST are scrutinized, and the short-term effects of the repurchase announcements made by these companies on the returns of shares of the relevant companies are examined.

Within the scope of the research, the share repurchase announcements made by publicly quoted companies traded in BIST between 04.01.2010 and 27.06.2018 were examined. As a result, a total of 146 repurchase announcements by 111 different companies were found to be made on different dates. By the year and by the industry distributions of these repurchase announcements identified are given in the tables below. 


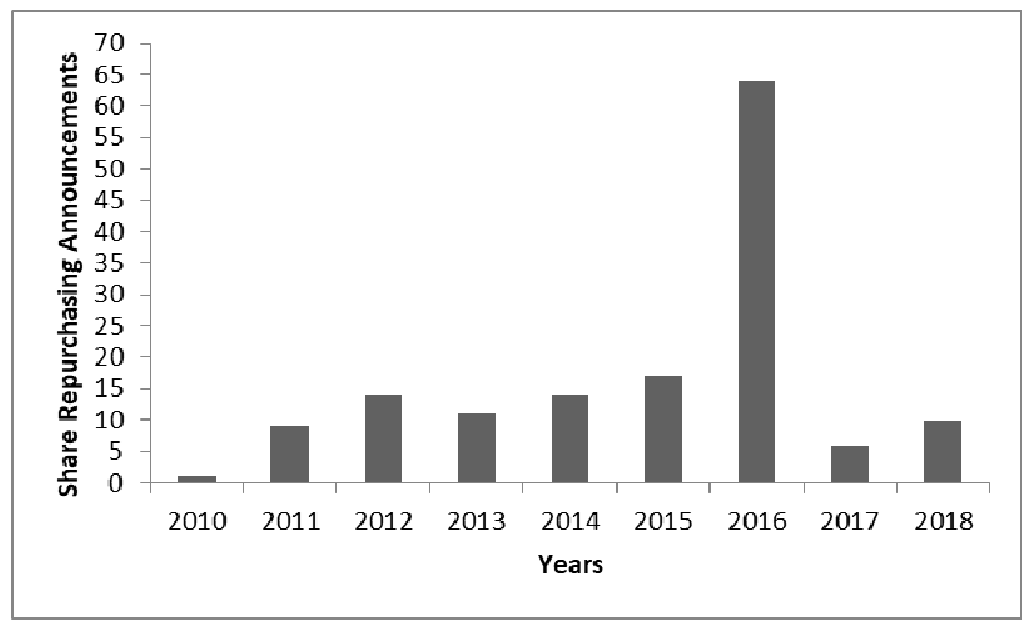

Figure 3.1. Distribution of Share Repurchasing Announcements by Years

In the figure above, the distribution of the repurchase announcements made in BIST according to the years is given. Accordingly, it is observed that the share repurchase announcements were made the least in 2010. The fact that only 1 share repurchase announcement was made in 2010 could be explained by the fact that the restrictions on share repurchase practices have yet to be lifted and share repurchase practices were very recent. In the following years, however, it is evident that the number of announcements of share repurchase practices increased gradually, and in fact this number peaked in 2016. A total of 64 announcements were identified in 2016. Of course, there are also the effects of the crisis experienced on 15 July 2016 in Turkey herein. In fact, this is one of the characteristic features of share repurchase practices. Because, share repurchase practices can be used intensively in

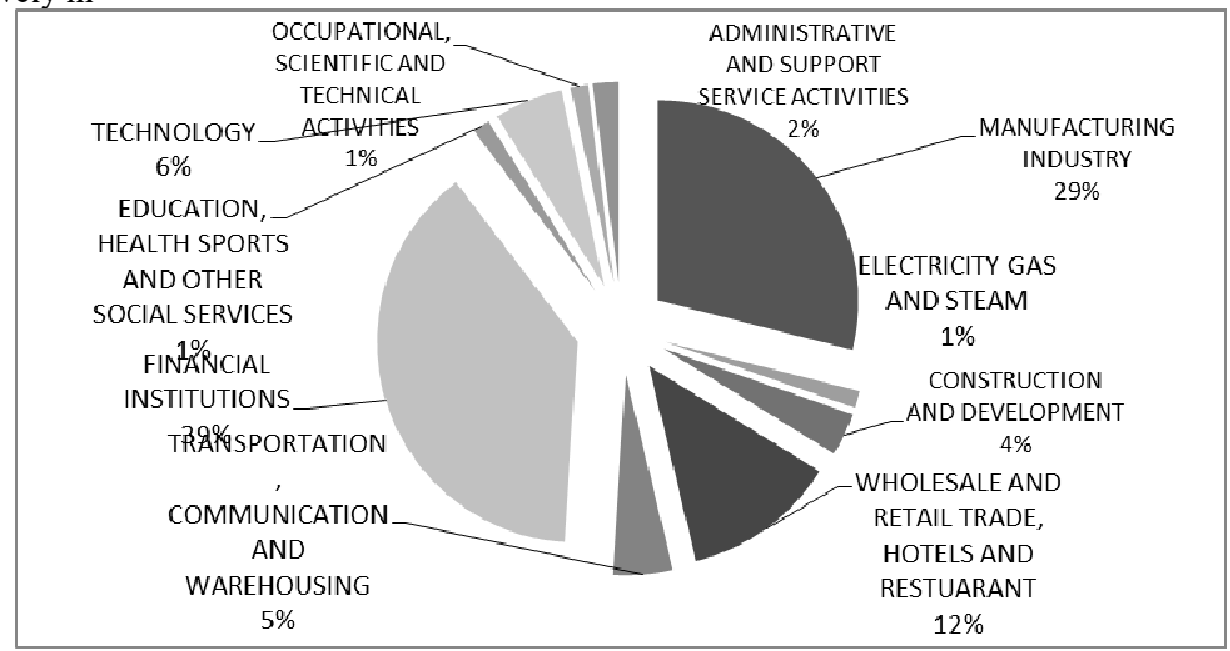

Figure 3.2. Distribution of Share Repurchase Announcements by Industries

In the study, distribution of share repurchase announcements by sectors is also presented. As exhibited in the figure, it is seen that the highest share repurchase announcements were realized in the Financial Institutions industry with $39 \%$, whereas followed by the Manufacturing Industry with $29 \%$.

Within the scope of the study, data such as the returns belonging to the companies which made the identified share repurchase announcements, BIST 100 return index, and the dates of the share repurchase announcement are utilized. Also, within the scope of the study, which factors affected the share repurchasing decisions of companies are examined. The factors determined in this context are given in the tables in the following sections.

Within the scope of the study, Event Study analysis was used to determine the effects of share repurchasing announcements on share returns. The event study analysis is a frequently used method in the detection of abnormal returns. This method was first used by Dolly in 1933 and has been the preferred method of many studies until today. Being a method that avails itself to be utilized in many different fields such as finance, accounting, economics and marketing, event study nowadays is being used as a statistical method in the field of finance to determine the effect of an event on the firm value.

Economic and statistical models are used in the calculation of abnormal returns. While economic models 
are models based on an economic theory such as capital asset pricing model (CAPM) and arbitrage pricing model, statistical models are models that are not based on any economic theory and set out from various statistical assumptions about price behavior. Among these models, market model, factor model and fixed average return model can be counted.

Consequently, the market model is preferred in this study, and the equation of this model and what the parameters of this equation mean are explained below;

$\mathrm{ARi}, \mathrm{t}=\mathrm{Ri}, \mathrm{t}-(\alpha \hat{+}+\beta$ i Rmt $)$

$\mathrm{ARi}, \mathrm{t}$ : is the abnormal return of the share $\mathrm{i}$ calculated on the day $\mathrm{t}$,

$\mathrm{Ri}, \mathrm{t}$ : is the actualized return of the share $\mathrm{i}$ calculated on the day $\mathrm{t}$,

Rmt : is the return of the market index on the day t. As a return of the market, return of BIST 100 Index is included in the model.

$\alpha^{\wedge}$ and $\beta \hat{i}$ values on the other hand, are parameters calculated for the $-255,-21$ period.

Subsequent to collecting abnormal returns (AR) obtained with the help of the specified parameters in the context of the related event windows, cumulative abnormal return (CAR) values are calculated.

Andriosopoulos and Lasfer (2015) were referenced as the estimated time to be used, by considering this duration would cover a period of one year prior to the day of the event, -255, -21period was addressed. Furthermore, similar to Ikenberry et al. (1995), Peyer and Vermaelen (2005), Zhang (2005), and Isa and Lee (2014), event windows are considered as 20 days before the event and 20 days after the event, and the duration is constituted within a period of 41 days as -20 , and +20 .

According to this, event windows are determined as, pre-event; $(-20,-1),(-10,-1),(-5,-1)$ and $(-3,-1),(-1,0)$ and $(0,0)$ post-event; $(0,+20),(0,+10),(0,+5),(0,+3)$ and $(0,1)$ encompassing both pre and post-event $(-20$, $+20),(-10,+10),(-5,+5),(-3,+3),(-1,+1)$ and $(-1,+2)$. Average abnormal returns (AAR), and cumulative average abnormal returns (CAAR) were calculated based on abnormal returns (AR) calculated for each event window.

\section{Emprical Results}

In this section, where all share repayment announcements made in Borsa Istanbul (BIST) are discussed, firstly, the average abnormal return calculations belonging to the total of 41 days including 20 days before, 20 days after the announcement day and the day of the announcement, as well as their pertinent statistical values are given at the table and graph below.

Table 4.1. AAR Values Calculated in Relation to Share Repurchase Announcements

\begin{tabular}{|c|ccccccc|}
\hline Day & AAR & t-Test & Prob. & Patell Z & Prob. & Corrado Rank & Prob. \\
\hline-20 & -0.003 & -1.710 & 0.090 & -1.940 & 0.050 & -1.530 & 0.130 \\
-19 & -0.003 & -1.590 & 0.110 & -1.250 & 0.210 & -0.690 & 0.490 \\
-18 & -0.003 & -1.300 & 0.190 & -1.560 & 0.120 & -1.210 & 0.230 \\
-17 & -0.002 & -0.810 & 0.420 & -0.410 & 0.680 & -0.670 & 0.500 \\
-16 & 0.001 & 0.670 & 0.510 & 0.370 & 0.710 & -0.170 & 0.860 \\
-15 & 0.001 & 0.570 & 0.570 & 0.230 & 0.820 & 0.480 & 0.630 \\
-14 & -0.003 & -1.300 & 0.190 & 0.350 & 0.730 & -0.070 & 0.950 \\
-13 & -0.008 & -3.870 & 0.000 & -4.220 & 0.000 & -3.150 & 0.000 \\
-12 & -0.005 & -2.330 & 0.020 & -1.340 & 0.180 & -0.920 & 0.360 \\
-11 & -0.002 & -0.930 & 0.350 & -1.290 & 0.200 & -1.170 & 0.240 \\
-10 & -0.002 & -1.210 & 0.230 & -1.020 & 0.310 & -0.250 & 0.800 \\
-9 & -0.002 & -1.190 & 0.230 & -1.780 & 0.070 & -0.070 & 0.950 \\
-8 & 0.001 & 0.360 & 0.720 & 0.080 & 0.930 & -0.240 & 0.810 \\
-7 & -0.003 & -1.620 & 0.110 & -2.170 & 0.030 & -1.280 & 0.200 \\
-6 & -0.001 & -0.280 & 0.780 & -0.020 & 0.980 & -0.460 & 0.650 \\
-5 & -0.006 & -3.180 & 0.000 & -4.300 & 0.000 & -2.040 & 0.040 \\
-4 & -0.011 & -5.340 & 0.000 & -5.230 & 0.000 & -2.640 & 0.010 \\
-3 & -0.008 & -3.980 & 0.000 & -3.740 & 0.000 & -1.230 & 0.220 \\
-2 & -0.013 & -6.230 & 0.000 & -5.230 & 0.000 & -3.290 & 0.000 \\
-1 & -0.001 & -0.560 & 0.570 & -1.470 & 0.140 & -0.180 & 0.860 \\
\cline { 2 - 7 } 0 & 0.022 & 11.180 & 0.000 & 13.070 & 0.000 & 5.900 & 0.000 \\
\cline { 2 - 7 } 1 & 0.015 & 7.230 & 0.000 & 9.990 & 0.000 & 4.220 & 0.000 \\
2 & 0.000 & -0.050 & 0.960 & 0.110 & 0.920 & -1.180 & 0.240 \\
3 & -0.001 & -0.340 & 0.730 & -1.530 & 0.130 & -1.760 & 0.080 \\
4 & -0.001 & -0.250 & 0.800 & -0.050 & 0.960 & -1.140 & 0.250 \\
5 & -0.001 & -0.240 & 0.810 & -1.000 & 0.320 & -1.580 & 0.120 \\
6 & -0.003 & -1.270 & 0.200 & -0.750 & 0.450 & -0.020 & 0.980 \\
\hline
\end{tabular}




\begin{tabular}{|c|ccccccc|}
\hline Day & AAR & t-Test & Prob. & Patell Z & Prob. & Corrado Rank & Prob. \\
\hline 7 & 0.001 & 0.260 & 0.790 & 0.050 & 0.960 & -0.020 & 0.980 \\
8 & 0.002 & 0.950 & 0.340 & 0.030 & 0.980 & 0.910 & 0.370 \\
\hline 9 & 0.001 & 0.640 & 0.520 & 1.760 & 0.080 & 0.350 & 0.730 \\
10 & 0.000 & 0.130 & 0.900 & 0.050 & 0.960 & -0.280 & 0.780 \\
11 & 0.001 & 0.440 & 0.660 & -0.030 & 0.970 & 0.090 & 0.930 \\
12 & -0.001 & -0.670 & 0.500 & -0.770 & 0.440 & -1.050 & 0.290 \\
13 & 0.003 & 1.580 & 0.110 & 1.630 & 0.100 & 0.930 & 0.350 \\
14 & -0.001 & -0.620 & 0.540 & -0.870 & 0.380 & -0.800 & 0.430 \\
15 & 0.002 & 1.040 & 0.300 & 0.840 & 0.400 & 0.900 & 0.370 \\
16 & -0.001 & -0.530 & 0.600 & 0.430 & 0.660 & -0.650 & 0.520 \\
17 & 0.000 & 0.200 & 0.840 & -0.050 & 0.960 & -0.030 & 0.970 \\
18 & -0.001 & -0.520 & 0.610 & -1.000 & 0.320 & -0.670 & 0.500 \\
19 & 0.003 & 1.480 & 0.140 & 0.830 & 0.410 & 0.780 & 0.430 \\
20 & 0.001 & 0.310 & 0.760 & 0.190 & 0.850 & 0.060 & 0.950 \\
\hline
\end{tabular}

According to this, as seen in the table, it was found that AAR values were generally negative in the twenty days period until the day (0) which indicates the date of announcement. However, this situation turned out to be positive with a $2.2 \%$ return on the announcement day, positive return continued within the next day, but with the third day following the announcement, emergence of fluctuations was observed in returns. This situation can be perceived more clearly with the following figure.

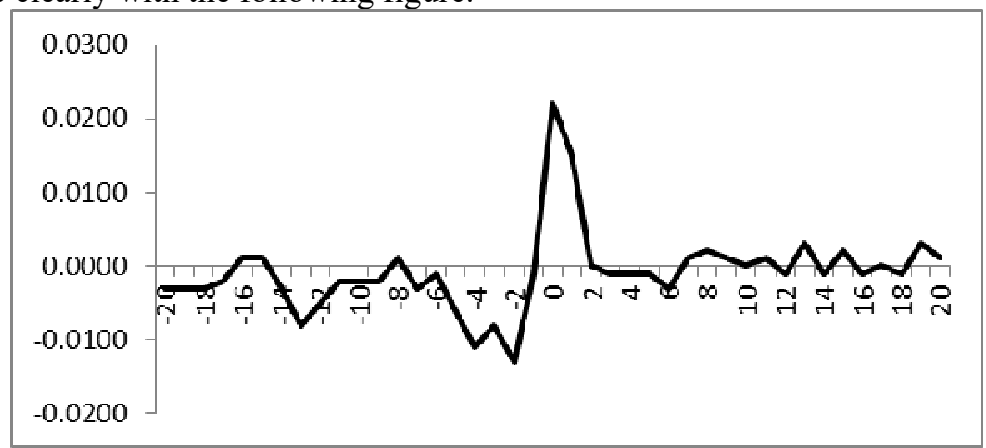

Figure 4.1. Graph of the AAR Values Calculated in Relation to Share Repurchase Announcements

When the cumulative average abnormal return (CAAR) graph, which is given below and determined between the $(-20,+20)$ corridor, is examined; similar to the AAR graph, it is observed that until day -1 the returns are negative directional, and the downward movement of the cumulative average abnormal return curve which continued until day 0 , in other words the day of the event, turned very sharply towards the positive, and the negative appearance in the cumulative average abnormal returns significantly decreased, and this situation continued until 1 day after the announcement, and then it continued its movement horizontally with minor fluctuations.

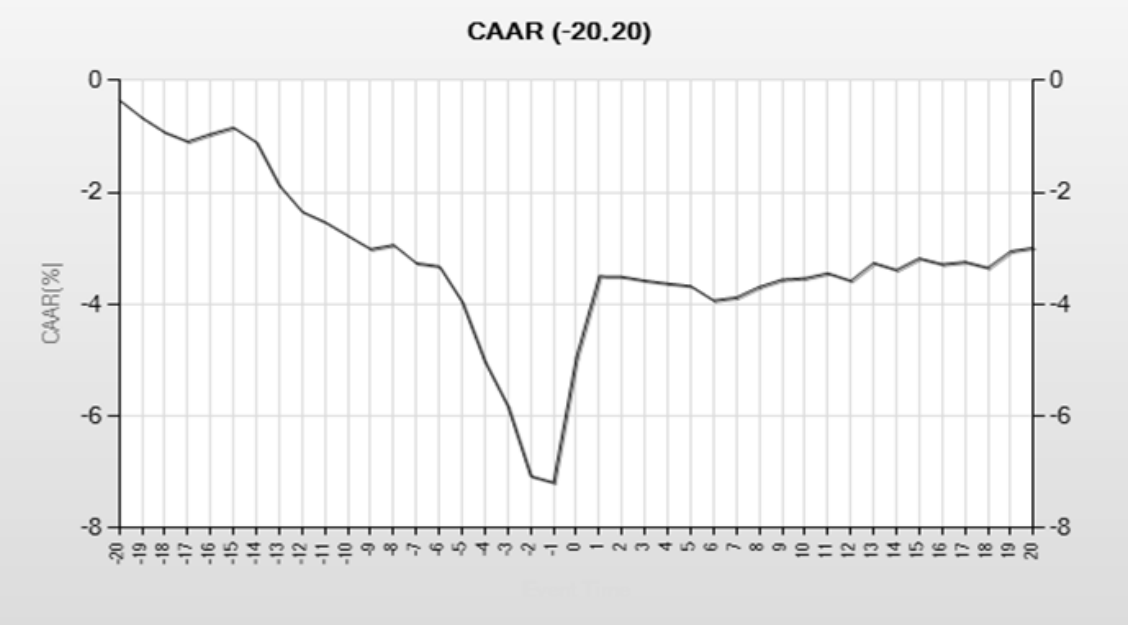

Figure 4.2 CAAR Graph Calculated in Relation to Share Repurchase Announcements

The following table shows the event windows, which are specified in the pre-announcement period, showing different day intervals, and the CAAR values calculated for these event windows, as well as the pertinent statistical values. 
Table 4.2. CAAR Values Related to the Period Prior to Share Repurchase Announcements

\begin{tabular}{|l|ccccccc|}
\hline Event Window & CAAR & t-Test & Prob. & Patell Z & Prob. & Corrado Rank & Prob. \\
\hline$(-20 \ldots-1)$ & -0.072 & -8.017 & 0.000 & -8.037 & 0.000 & -4.648 & 0.000 \\
$(-10 \ldots-1)$ & -0.047 & -7.350 & 0.000 & -7.867 & 0.000 & -3.694 & 0.000 \\
$(-5 \ldots-1)$ & -0.039 & -8.631 & 0.000 & -8.932 & 0.000 & -4.196 & 0.000 \\
$(-3 \ldots-1)$ & -0.022 & -6.223 & 0.000 & -6.029 & 0.000 & -2.716 & 0.007 \\
$(-1 \ldots 0)$ & 0.021 & 7.508 & 0.000 & 8.205 & 0.000 & 4.041 & 0.000 \\
\hline
\end{tabular}

When the event windows of the pre-announcement period were examined, the negative CAAR values were calculated in all other event windows except the $(-1,0)$ event window, and the event window with the lowest CAAR value, with a loss of $7.2 \%$ was determined to be the $(-20,-1)$ event window. When the event windows are examined, it is observed that the effect of the negative appearance decreased as the date of the announcement approached and as the day interval in the event windows narrowed. In addition, when the statistical values and significance levels calculated for all the specified event windows are analyzed, it is seen that the calculated CAAR values for all event windows are statistically significant.

Table 4.3. CAAR Values Related to the Period Following Share Repurchase Announcements

\begin{tabular}{|c|ccccccc|}
\hline Event Window & CAAR & t-Test & Prob. & Patell Z & Prob. & Corrado Rank & Prob. \\
\hline $\mathbf{( 0 . . . 2 0 )}$ & 0.042 & 4.574 & 0.000 & 5.007 & 0.000 & 1.081 & 0.280 \\
$\mathbf{( 0 . . . 1 0 )}$ & 0.037 & 5.499 & 0.000 & 6.556 & 0.000 & 1.623 & 0.105 \\
$(\mathbf{0 . . . 5 )}$ & 0.035 & 7.157 & 0.000 & 8.411 & 0.000 & 1.820 & 0.069 \\
$(\mathbf{0 . . . 3 )}$ & 0.036 & 9.009 & 0.000 & 10.822 & 0.000 & 3.587 & 0.000 \\
$(\mathbf{0 . . . 1 )}$ & 0.037 & 13.022 & 0.000 & 16.309 & 0.000 & 7.157 & 0.000 \\
\hline
\end{tabular}

On the other hand, when event windows determined during the 20-day period following the announcement was made are examined, in contrast to the event windows determined in the pre-announcement period, positive CAAR values were calculated in all event windows. In addition, the CAAR values calculated for event windows appear to be statistically significant for all windows. When the calculated CAAR values are examined, although the event window, where the CAAR value is calculated the highest, is observed to be a $(0,+20)$ window with a value of $4.2 \%$, the effect of the $3.7 \%$ value detected in the $(0,+1)$ event window appears to be relatively larger. These calculated CAAR values demonstrate that share prices have yielded a favorable response to the share repurchase announcements in the short-term, in other words, that share repurchase announcements have an effect on the share returns. Despite the expansion of the time interval based on other windows except the $(0,+1)$ event window, the small increases observed in CAAR values point to the horizontal movement observed in the returns from the second day following the issuance of the announcement. In other words, it was determined that the upward jump observed as the first reaction of the share returns to the announcements gave its place to reaching a balance with the second day, and that the prices started to cling on to a certain level.

Table 4.4. CAAR Values for the Combined Period Covering the Period Before and After the Share Repurchasing

Announcements

\begin{tabular}{|c|ccccccc|}
\hline Event Windows & CAAR & t-Test & Prob. & Patell Z & Prob. & Corrado Rank & Prob. \\
\hline $\mathbf{( - 2 0 . . . 2 0 )}$ & -0.030 & -2.326 & 0.020 & -2.030 & 0.042 & -2.472 & 0.013 \\
$\mathbf{( - 1 0 . . . 1 0 )}$ & -0.010 & -1.092 & 0.275 & -0.684 & 0.494 & -1.374 & 0.169 \\
$\mathbf{( - 5 . . . 5 )}$ & -0.004 & -0.533 & 0.594 & 0.190 & 0.850 & -1.484 & 0.138 \\
$\mathbf{( - 3 . . . 3 )}$ & 0.015 & 2.736 & 0.006 & 4.234 & 0.000 & 0.934 & 0.351 \\
$\mathbf{( - 1 . . . 1 )}$ & 0.036 & 10.307 & 0.000 & 12.470 & 0.000 & 5.738 & 0.000 \\
$\mathbf{( - 1 . . . 2 )}$ & 0.036 & 8.899 & 0.000 & 10.852 & 0.000 & 4.378 & 0.000 \\
\hline
\end{tabular}

Moreover, when the combined event windows covering pre-event and post-event days are examined, the highest CAAR value is calculated in the event window $(-1,+1)$ with a rate of $3,6 \%$, and this was followed by the event window $(-3,+3)$ with a rate of $1.5 \%$. However, it was determined that the CAAR values were negative in the combined event windows covering longer periods, and the lowest CAAR value was calculated in the event window $(-20,+20)$ with a loss of $3 \%$, followed by the event window $(-10,+10)$ with loss of $1 \%$.

\section{Conclusion}

The practice of share repurchasing has become increasingly significant among the instruments utilized by companies for the distribution of cash to its shareholders throughout the years. Nowadays, many companies prefer to repurchase some of their shares from the market instead of paying dividends. The main reason for this might be attributed to the flexibility offered to companies within this mechanism. Share repurchases are absolutely non-binding practices. Companies can spend billions on repurchase programs within a year and write them off as expenses in the year that follows. On the other hand, dividends come with their specific obligations, and the reduction or cancellation of dividends may have an adverse effect on share prices. In order to repurchase shares, companies in addition to having different options, there are also different motivations that make companies purchase these back as well. In line with these motivations emerged, billions of dollars' worth of 
share repurchases are actualized annually in international markets.

Quickly becoming popular in international markets, stock repurchases in Turkey however, only began to be implemented after 2009. The developments encountered in 2009 and beyond, as well as the successive arrangements made, have led to an increase in the number of companies that have engaged in share repurchasing practices. Nonetheless, despite the increasing interest of companies in share repurchasing, it is observed that domestic literature is quite limited in this area, and studies carried out have not gone beyond a few. For this reason, a study that will contribute to the domestic literature especially on domestic share repurchasing operations is intended to be presented.

Within the scope of the study, share repurchase announcements in the period between 2010-2018 are tried to be determined. As a result of the investigations, a total of 146 repurchase announcements of publicly traded publicly traded companies within the period specified were identified. The effect of these share repurchase announcements on the share returns was analysed empirically by the Event Study method, and the findings obtained were analysed. Accordingly, in order to measure the share return performance within the short term following the repurchase announcements made by the companies identified, an event window $(-20,+20)$ was opened in the length of a total of 41 working days, including "20 working days" before, and "20 working days" after the day when the announcement was made. Within the scope of this event window, sub-event windows were opened to cover the pre-event, post-event and the combined period. For these identified event windows, the AAR and CAAR values of the shares were examined, and through this examination, the changes in the returns related to those announcements were observed.

According to the findings obtained as a result of examining the effects of share repurchase announcements on share returns; AAR values in the 20-day period prior to the announcement of public disclosures of the shares repurchase transactions are observed to be at a negative level in general. This situation has changed with the public disclosure of the announcements related to the repurchase transaction, and the direction of the AAR values has been positive, albeit for a short-term. Following this, a period where relatively low fluctuations realized in AAR values were seen, was entered.

In the study, pre-announcement, post-announcement and combined period were also discussed, and subevent windows with different date ranges were opened within the periods specified in this scope. In this way, the CAAR values expressing the cumulative sum of the calculated AAR values for the date range expressed by each event window were determined independently. According to this, a positive AAR of $2.2 \%$ was found in share returns as a result of share repurchasing announcements made in BIST at the date of announcement. In other words, on the announcement date, an investor has a chance to obtain an average abnormal return (AAR) such as $2.2 \%$. This rate was calculated to be $1.47 \%$ for Germany in the study of Hackethal and Zdantchouk (2006), about $1 \%$ for Japan in the study of Hatakeda and Isagawa (2004), and 0,60\% for Taiwan in the study of Liao et al. (2005). Additionally, the study by Lee, Ejara and Gleason (2010) has calculated this ratio for France, Germany, Italy and the United Kingdom, and has achieved 0,02\%, 2,76\%, 0,97\%, and $\%$ 0,52 results respectively.

When the event windows for the pre-announcement period are reviewed, negative CAAR values were calculated in all other event windows except for the event window $(-1,0)$, also including the announcement date, and the event window with the lowest CAAR value, with a loss of $7.2 \%$, is determined to be the event window ($20,-1)$. When the event windows are examined, it is observed that the effect of the negative outlook decreased as the date of announcement is approached and the day interval in the event windows narrowed. While Hatakeda and Isagawa (2004) reported that the negative CAAR value in the period prior to the announcement date was calculated as $-4.82 \%$ for Japan, Seifert and Stehle (2005) on the other hand, have addressed the period before the announcement date as $(-25,-1)$ for Germany and expressed that the calculated CAAR value for this period was 6.43\%. Moreover, Isa and Lee (2014), Chatterjee and Dutta (2015) and Gan, Bian, Wu and Cohen (2017), for Malaysia, India and China, respectively, put forward that positive CAAR values had been calculated in the $(-20$, -1) event window prior to the announcement date.

When the event windows identified from the 20-day period following the issuance of the announcement; unlike the event windows determined for the period prior to the announcement, positive CAAR values are calculated in all event windows. When the calculated CAAR values are examined; although the event window with the highest CAAR value calculated, with a value of $4.2 \%$, is observed to be the event window $(0,+20)$, the CAAR value of $3.7 \%$ detected in the event window $(0,+1)$ is also noteworthy. These calculated CAAR values demonstrate that share prices have yielded a favourable response to the share repurchase announcements in the short-term, in other words, that share repurchase announcements have an effect on the share returns. Despite the expansion of the time interval based on other windows except the $(0,+1)$ event window, the small increases observed in CAAR values point to the horizontal movement observed in the returns from the second day following the issuance of the announcement. In other words, it was determined that the upward jump observed as the first reaction of the share returns to the announcements gradually lost its effect with the second day, and that gave its place to reaching a balance.

Seifert and Stehle (2005) considered the period after the announcement for Germany as $(+1,+25)$, and 
expressed that the calculated CAAR value for this period was $0.72 \%$. In the study conducted by Liao et al. (2006) where the effect of repurchase announcements made in Taiwan on returns was examined; for the event window $(0,+20)$ where the post-announcement period was considered, it was indicated that the CAAR value was calculated as 10,39\%. Moreover, in the study conducted by Rasbant (2013) in which the effect of share repurchase announcements in Sweden on returns was examined; for the event window $(+2,+20)$ where the postannouncement period was considered, it was indicated that the CAAR value was calculated as $-0.53 \%$. Whereas Isa and Lee (2014), in the conclusion of their study conducted for Malaysia; for the event window $(+2,+20)$ where the post-announcement period was considered, it was indicated that the CAAR value was calculated as $1.6 \%$. Chatterjee and Dutta (2015) for India, in the $(0,+20)$ event window, CAAR value was found to be $0.3 \%$.

Furthermore, when the combined event windows covering the days before and after the event are examined; it was determined that the highest CAAR value was calculated in the event window $(-1,+1)$ with a rate of $3,6 \%$. As a result of reviewing the repurchase announcements made in international markets, the calculated CAAR values for the event window $(-1,+1)$ are as follows; among the studies addressing the markets in the United States, Comment and Jarrell (1991), determined 2.3\%, McNally (1999) 2.5\% and Grullon / Michaley (2004) 2.7\%, respectively. Again, Manconi, Peyer and Vermaelen (2015) calculated global CAAR values outside the United States and the United States, which were determined to be $2.15 \%$ for the US and $1.42 \%$ for non-US countries, respectively. $\mathrm{n}$ the study conducted by Hackethal and Zdantchouk (2006), where the impact of repurchase announcements on Germany was examined; this rate was determined as $2.53 \%$, and in the case of UK, another country in Europe, Lasfer (2005) and Rau, and Vermaelen (2002), calculated this rate as 1.64\% and $1.08 \%$, respectively. In the meantime, in the studies conducted on share repurchasing announcements made in Asian markets such as China, Japan, Taiwan and India; the calculated CAAR values for the $(-1,+1)$ event window are determined in the study of Gan et al. (2017) as 2.64\%, Hatakeda and Isagawa (2004) as 1.24\%, Liao (2006) as $2.96 \%$ and Chatterjee and Dutta (2015) as $0.18 \%$, respectively.

When the CAAR values calculated at the conclusion of the repurchase announcements made in international markets are taken into consideration; the impact of the share repurchase announcement returns of the shares held in Turkey seems to be higher in comparison to many other countries. This situation illustrates that the repurchase announcements made in order to create a value for investors and shareholders and to protect them have been successful in this regard in the short term. According to this, compared to many other countries, investors in the Turkish market may have a higher chance of obtaining abnormal returns, by courtesy of share repurchase announcements which are made in the $(-1,+1)$ event window

\section{References}

Andriosopoulos, D., and Lasfer M. (2015). The market valuation of share repurchases in Europe. Journal of Banking \& Finance 55: 327-339.

Chan K., Ikenberry D., and Lee I., (2004). Economic sources of gain in stock repurchases. Journal of Financial and quantitative Analysis 39.03: 461-479.

Chatterjee C., and Dutta P.,(2015). Anomalous Price Behaviour around Open Market Stock Repurchase Announcements in India. Vikalpa 40.4: 435-443.

Comment, R., and Jarrell G. A., (1991). The relative signalling power of Dutch-auction and fixed-price self-tender offers and open-market share repurchases. The Journal of Finance 46.4: 1243-1271.

Fox, J., (2018). The Big and Possibly Dumb Buyback Boom. www.Bloomberg.com

https://www.bloomberg.com/view/articles/2018-03-06/the-big-and-possibly-dumb-boom-in-corporate-sharebuybacks

Gan, C., Bian, C., Wu, D., \& Cohen, D. A. (2017). Determinants of share returns following repurchase announcements in China.

Grullon G., and Michaely R., (2002). Dividends, share repurchases, and the substitution hypothesis. The Journal of Finance 57.4: 1649-1684.

Grullon, G., \& Michaely, R. (2004). The Information Content of Share Repurchase Programs. The Journal of Finance, 59 (2), 651-680.

Hackethal, A., \& Zdantchouk, A. (2006). Signaling Power of Open Market Share Repurchases in Germany. Financial Markets and Portfolio Management, 20, 123-151.

Hatakeda, T., \& Isagawa, N. (2004). Stock Price Behavior Surrounding Stock Repurchase Announcements: Evidence from Japan. Pacific-Basin Finance Journal, 12, 271-290.

Ikenberry D., Lakonishok J., and Vermaelen T., (1995). Market underreaction to open market share repurchases. Journal of financial economics $39.2: 181-208$.

Ikenberry, D., Lakonishok, J., \& Vermaelen, T. (2000). Stock repurchases in Canada: Performance and strategic trading. The Journal of Finance, 55(5), 2373-2397.

Isa, M., and Lee S. P., (2014). Market Reactions to Share Repurchase Announcements in Malaysia. Asian Academy of Management Journal of Accounting and Finance 10.1: 45-73. 
Lakonishok J., and Vermaelen T.,(1990). Anomalous price behavior around repurchase tender offers. The Journal of Finance 45.2 (1990): 455-477.

Lasfer, M. A. (2000). The market valuation of share repurchases in Europe. City University Business School.

Lee, C. I., Ejara, D. D., \& Gleason, K. C. (2010). An empirical analysis of European stock repurchases. Journal of multinational financial management, 20(2-3), 114-125.

Liao, T. L., Ke, M. C., \& Yu, H. T. (2005). Anomalous price behaviour around stock repurchases on the Taiwan stock exchange. Applied Economics Letters, 12(1), 29-39.

Manconi, A., Peyer, U., \& Vermaelen, T. (2015). Buybacks around the world: Market Timing, Governance and Regulation. knowledge.insead.edu,

http://knowledge.insead.edu/sites/www.insead.edu/files/images/1bb_around_the_world_revised_september_8_2015-2.pdf

Netter J. M. and Mitchell M. L. (1989). Stock-repurchase announcements and insider transactions after the October 1987 stock market crash. Financial Management: 84-96.

McNally W. J., Smith B. F. and Barnes T., (2006). The price impacts of open market repurchase trades. Journal of Business Finance \& Accounting33.5-6: 735-752.

Peyer, U. C., \& Vermaelen, T. (2005). The many facets of privately negotiated stock repurchases. Journal of Financial Economics, 75(2), 361-395.

Peyer U., and Vermaelen T., (2009). The nature and persistence of buyback anomalies. Review of Financial Studies 22.4: 1693-1745.

Rau, P. R., \& Vermaelen, T., (2002). Regulation, taxes, and share repurchases in the United Kingdom. The Journal of Business, 75(2), 245-282.

Skinner, D. J., (2008). The evolving relation between earnings, dividends, and stock repurchases. Journal of financial economics, 87(3), 582-609.

Seifert, U., \& Stehle, R. (2005). Stock performance around share repurchase announcements in Germany.

Vermaelen T., (1981). Common stock repurchases and market signalling: An empirical study. Journal of financial economics 9.2: 139-183.

Vermaelen T., (1984). Repurchase tender offers, signaling, and managerial incentives. Journal of Financial and Quantitative Analysis 19.02: 163-181.

Yook, K. C. (2010). Long-run stock performance following stock repurchases. The Quarterly Review of Economics and Finance, 50(3), 323-331.

Zhang H., (2005). Share price performance following actual share repurchases. Journal of Banking \& Finance 29.7: 1887-1901. 